\title{
In Vitro Packaging of Bacteriophage T7 DNA Synthesized In Vitro
}

\author{
WARREN E. MASKER,* NANCY B. KUEMMERLE, AND DAVID P. ALLISON \\ Biology Division, Oak Ridge National Laboratory, Oak Ridge, Tennessee 37830
}

Received for publication 17 February 1978

\begin{abstract}
An in vitro DNA packaging system was used to encapsulate T7 DNA that had been synthesized by extracts prepared from gently lysed Escherichia coli infected with bacteriophage T7 carrying amber mutations in gene 3 or in both genes 3 and 6. Isopycnic centrifugation of density-labeled wild-type DNA was employed in an effort to separate product from template; suppressor-free indicator bacteria were used to eliminate contributions from endogenous DNA or contaminating phage. Additional controls indicated that fragmented DNA is packaged in vitro only with very low efficiency and that the frequency of recombination during packaging is too low to affect interpretation of these experiments. T7 DNA replicated by extracts prepared using T7 mutants deficient in both genes 3 and 6 could be packaged in vitro with an efficiency comparable to that found when highly purified virion T7 DNA was used. When T7 deficient in the gene 3 endonuclease but with normal levels of the gene 6 exonuclease was used, fast-sedimenting concatemer-like DNA structures were formed during in vitro DNA synthesis. Electron microscopy revealed many branched and highly complex DNA structures formed during this reaction. This concatemer-like DNA was encapsulated in vitro with an efficiency significantly greater than that found for DNA the length of a single $\mathrm{T} 7$ genome.
\end{abstract}

Bacteriophage T7 provides an excellent biological system with which to study DNA metabolic processes. This phage's linear, duplex, 25 $\times 10^{6}$-dalton DNA molecule has genetic coding capacity sufficient for about 30 genes, most of which have been positioned on a genetic map $(12,13,46,47)$. At least five phage-induced enzymes (the products of genes $2,3,4,5$, and 6 ) are required for normal in vivo DNA replication and phage production $(13,47)$. Of these, all except the product of gene 2 have been at least partially purified and characterized biochemically $(4,11,15,18,19,23,33,37,40,44)$. The DNA replication process itself seems almost elegantly simple in T7. After initiation at a unique site on the T7 chromosome, replication proceeds bidirectionally (7) and discontinuously (27) until the genome is duplicated. Soon after infection, concatemeric DNA structures equivalent in length to several T7 genomes are observed (10, $17,34,42,45)$; presumably, these are subsequently matured to monomer length before or during the packaging process. Maturation and packaging, which are still poorly understood processes, are carried out by the products of T7's late genes $(13,36,47)$.

The study of DNA replication and DNA packaging in T7 has been accelerated by the development of in vitro systems that can carry out each of these steps. In vitro T7 DNA synthesis systems $(14,43)$ that make use of crude or partially fractionated extracts prepared from lysates of T7-infected Escherichia coli have provided powerful tools for the purification of enzymes important in T7 DNA replication $(15,33,41)$. In vitro DNA synthesis in one of these systems seems to closely mimic in vivo DNA replication in that the product DNA has about the same single-strand molecular weight as a complete $\mathrm{T} 7$ chromosome, and the larger pieces of DNA synthesized in vitro can transfect $E$. coli spheroplasts to produce T7 phage $(29,30)$.

It is also possible to employ in vitro systems to study the packaging of T7 DNA into phage particles (20). The packaging of exogenous DNA into phage heads proceeds most efficiently when recombination occurs between exogenous DNA and the endogenous T7 DNA present in the crude extracts used for the in vitro packaging system $(38,39,48)$. However, when the amount of endogenous DNA (and the level of recombination) is reduced by use of extracts of $E$. coli infected with $\mathrm{T} 7$ carrying amber mutations in three genes (genes 3, 5, and 6) essential to DNA replication and recombination $(11,21,25,26,32)$, it is still possible to encapsulate highly purified exogenous T7 DNA into complete phage particles with an average efficiency of over $10^{-4}$ phage 
produced per $\mathrm{T} 7$ genome equivalent of DNA and in direct proportion to the amount of DNA added to the reaction (24). This system offers efficiencies significantly higher than those attainable with spheroplast assays $(1,8)$, a feature which makes it attractive for monitoring biological activity of T7 DNA. Since a point of concern in the previous demonstration of in vitro synthesis of biologically active T7 DNA (30) was the low efficiency of phage production observed after transfection, it was of interest to attempt to package in vitro the T7 DNA produced by an in vitro DNA synthesis system. The experiments reported here show that DNA synthesized in vitro can subsequently be packaged in vitro to form viable phage.

The precise mechanism which allows DNA synthesized in vitro to be encapsulated and form viable phage is obscure. Nor is it immediately obvious how a linear duplex DNA molecule can be terminated by the enzymatic replication machinery without some loss of genetic information. One model (49) which offers a plausible mechanism for termination relies upon recombination and subsequent concatemer formation to provide a suitable primer-template configuration for synthesis of the terminally redundant ends of the T7 chromosome. Thus far, there has been little evidence for in vitro concatemer formation by extracts of $E$. coli infected with T7 carrying amber mutations in genes 3 and 6 , and, since the products of these genes are not essential to in vitro DNA synthesis, most experiments have been performed with phage mutant in these genes $(15,29,30)$. Evidence has accumulated that indicates an essential role for the gene 6 exonuclease in recombination and in concatemer formation in vivo when the gene 3 endonuclease is present (32). However, there are suggestions $(10,32)$ that some concatemers appear in vivo in $E$. coli infected with T7 deficient in both the gene 3 and gene 6 products, indicating that the gene 6 exonuclease is required for concatemer formation only in the presence of the gene 3 product (32). Thus, it is possible that DNA molecules longer than a single genome may constitute a minor component of the DNA produced in vitro. The endonuclease coded for by gene 3 appears to be at least partially responsible for cleaving T7 DNA concatemers, since concatemers accumulate in $E$. coli after infection with a gene 3 -deficient mutant $(34,43,45)$. Encouraged by these reports, we examined DNA molecules produced in vitro by extracts prepared from wild-type $E$. coli infected with T7 deficient only in the gene 3 product. Our experiments reveal concatemer-like DNA molecules produced during in vitro DNA synthesis. A comparison of the in vitro packaging efficiency of single-genome-long T7 DNA with that of fastsedimenting structures produced in vitro showed that the DNA in the longer molecules is in fact more biologically active than that in the monomer-size counterparts.

\section{MATERIALS AND METHODS}

Bacterial strains and bacteriophage. The strains of $E$. coli $\mathrm{K}-12$ used in this study included W3110, thy, JC5088, Hfr KL16 thr ilv recA56; WM279, thy recA56, derived from $\mathrm{W} 3110$ by conjugation with JC5088 and selection for UV-sensitive thymine prototrophs; and $011^{\prime}$, thy sup ${ }^{+}$.

Bacteriophage T7 and amber mutants thereof, from F. W. Studier, were grown as described (46). The amber mutations used in this study were: gene 1 , am 23; gene 3, am 29; gene 4, am 20; gene 5, am28; gene 6, am 147; and gene 19,am10. In the text, T7 mutants are designated by subscript notation indicating gene only, e.g., $T 7_{3,6}$ refers to the double amber mutant $a m 29$ and $a m 147$.

Media and chemicals. L-broth, T-agar, and M9 media have been described by Miller (31); L-broth was routinely supplemented with $10 \mu \mathrm{g}$ of thymine per $\mathrm{ml}$ and $0.1 \%$ (wt/vol) glucose.

Suppliers were as follows: ribonucleoside and deoxyribonucleoside triphosphates, Schwarz/Mann; spermidine, Sigma; bovine serum albumin, Miles Laboratories; $\left[{ }^{13} \mathrm{C}\right]$ glucose and ${ }^{15} \mathrm{NH}_{4} \mathrm{Cl}$ for density labeling, Merck, Sharp, and Dohme and BioRad, respectively; $\left[\alpha^{32} \mathrm{P}\right] \mathrm{dATP}, \mathrm{New}$ England Nuclear; $\left[{ }^{3} \mathrm{H}\right]$ thymidine, Schwarz/Mann; lysozyme, Calbiochem; proteinase K, Merck; and Sarkosyl NL97, CIBA-Geigy.

DNA. Unlabeled and ${ }^{3} \mathrm{H}$-labeled T7 DNAs were prepared from T7 phage grown on strain $011^{\prime}$ as described by Richardson (35). Density-labeled wild-type T7 DNA was prepared according to the procedure of Masker and Richardson (29). All DNA concentrations are expressed as nucleotide phosphorus equivalents.

Reaction conditions for in vitro synthesis of DNA. The preparation of extracts from T7-infected bacteria has been previously described $(14,28,50)$. Reaction mixtures (final volume, 0.1 to $0.6 \mathrm{ml}$ ) contained $30 \mathrm{mM}$ Tris-hydrochloride $(\mathrm{pH} 7.5) ; 20 \mathrm{mM}$ $\mathrm{MgCl}_{2} ; 10 \mathrm{mM}$ 2-mercaptoethanol; $0.3 \mathrm{mM}$ each rATP, rCTP, rGTP, rUTP, dATP, dTTP, dGTP, and dCTP; $0.03 \mathrm{mM}$ exogenous ${ }^{3} \mathrm{H}$ - or ${ }^{3} \mathrm{H}^{13} \mathrm{C}^{15} \mathrm{~N}$-labeled T7 DNA; and $0.02 \mathrm{ml}$ of $\mathrm{T}_{3}-$ or $\mathrm{T} 7_{3,6}$-infected extract of $E$. coli per $0.1-\mathrm{ml}$ final volume. Tracer amounts (5 to $15 \mathrm{cpm} / \mathrm{pmol}$ of DNA) of high-specific-activity $\left[\alpha-{ }^{32} \mathrm{P}\right] \mathrm{dATP}$ were added to reaction mixtures, which were then incubated at $30^{\circ} \mathrm{C}$ for 10 to $40 \mathrm{~min}$. Reactions were terminated by addition of EDTA to a concentration of $50 \mathrm{mM}$.

Zone sedimentation in alkaline and neutral sucrose. Prior to sucrose gradient analysis, 0.1-ml reaction mixtures were incubated for $10 \mathrm{~min}$ at $42^{\circ} \mathrm{C}$ with an equal volume of $20 \mathrm{mM}$ Tris-hydrochloride (pH 7.5), $1 \mathrm{M} \mathrm{NaCl}$, and 4\% Sarkosyl. Samples were cooled to room temperature before $0.1-\mathrm{ml}$ portions were layered onto 5 to $20 \%$ linear gradients $(3.5 \mathrm{ml})$ of neutral $(0.7 \mathrm{M} \mathrm{NaCl}, 0.05 \mathrm{M}$ Tris-hydrochloride [pH 7.5], $0.01 \mathrm{M}$ EDTA) or alkaline $(0.5 \mathrm{M} \mathrm{NaCl}, 0.01 \mathrm{M}$ EDTA, 0.2 $\mathrm{M} \mathrm{NaOH}$ ) sucrose; neutral gradients were 
formed on top of a $0.2-\mathrm{ml}$ shelf of $84 \%$ sucrose. Centrifugation in a Spinco SW56 rotor at $20^{\circ} \mathrm{C}$ was at $49,000 \mathrm{rpm}$ for $120 \mathrm{~min}$ in the case of alkaline gradients and at $17,500 \mathrm{rpm}$ for $35 \mathrm{~min}$ in the case of neutral gradients. Six-drop fractions were pumped out from the bottom of the tube, and $0.05 \mathrm{ml}$ of salmon sperm DNA at a concentration of $0.5 \mathrm{mg} / \mathrm{ml}$ was added to each fraction. Acid-insoluble radioactivity was precipitated by use of $4 \mathrm{ml}$ of ice-cold $1 \mathrm{~N} \mathrm{HCl}-0.1 \mathrm{M}$ sodium pyrophosphate and collected on Whatman GFC glassfiber filters soaked in $0.1 \mathrm{M}$ sodium pyrophosphate. The precipitates were washed three times with icecold acid pyrophosphate and once with $95 \%$ ethanol, dried, and counted for radioactivity in a solution of 3 g of Packard Permablend per liter of toluene.

Isopycnic gradient analysis. Reaction mixtures $(0.2$ to $0.6 \mathrm{ml}$ ) were brought to a volume of $1.0 \mathrm{ml}$ with cold NET buffer $(0.1 \mathrm{M} \mathrm{NaCl}, 0.01 \mathrm{M}$ EDTA, $0.01 \mathrm{M}$ Tris-hydrochloride [pH 8.0]). Samples for alkaline $\mathrm{CsCl}$ gradients were then denatured by the addition of $0.7 \mathrm{ml}$ of $1 \mathrm{M}$ potassium phosphate buffer ( $\mathrm{pH} 12.0$ at $50 \mathrm{mM}$ ). To $8.0 \mathrm{~g}$ of $\mathrm{CsCl}$ were added the sample and $1 / 10$ concentration of NET to produce a total weight of $14.0 \mathrm{~g}$. After centrifugation in a Spinco Ti50 rotor for $40 \mathrm{~h}$ at $37,000 \mathrm{rpm}$ and $20^{\circ} \mathrm{C}$, fractions (approximately $0.2 \mathrm{ml}$ ) were pumped through a hole punctured in the bottom of the centrifuge tube, and refractive indexes of neutral gradient fractions were measured. Aliquots $(0.02 \mathrm{ml})$ of each fraction were acid precipitated, and radioactivity was determined. Selected fractions of the gradients were pooled and dialyzed against two changes of 1,000 volumes of ice-cold $10 \mathrm{mM}$ Trishydrochloride (pH 7.5)-0.1 mM EDTA prior to packaging or further gradient analysis.

Reaction conditions for in vitro packaging of DNA. Extracts were prepared (24) from $E$. coli W 3110 infected with a mutant phage $\left(\mathrm{T} 7_{3,5,6}\right)$ incapable of DNA synthesis. As previously shown (24), the proteins present in these extracts are capable of encapsulating exogenously provided wild-type T7 DNA into phage heads so as to produce $\mathrm{T} 7$ phage that can form plaques on suppressor-free indicator bacteria. With this system, phage production is dependent upon exogenous DNA and is proportional to DNA concentration in the range of $1 \mathrm{pmol}$ to $1 \mathrm{nmol}$ per $30-\mu \mathrm{l}$ reaction. Details of the preparation of phage-infected cells and the exact reaction conditions have been published (24). For most experiments, the values shown for the numbers of infective centers are the averages of five separate determinations, each plated in duplicate; the standard deviation of values obtained from separate assays using the same extract was generally smaller than the $\pm 65 \%$ previously reported (24). Because individual extracts varied somewhat in their efficiency of packaging, each experiment included as a control a measurement of the number of infective centers produced from a known amount of untreated wild-type T7 DNA. Since different extracts were used to gather the data shown in individual tables, comparison of the absolute packaging efficiencies of various DNAs should only be made relative to the controls or to other DNAs shown in the same table. For convenience, relative packaging efficiencies, normalized to the value obtained with control DNA, are shown in several of the tables.

Electron microscopy. DNA samples were pre- pared for electron microscopy by the Inman and Schnös (16) modification of the protein film technique (22). Samples of DNA $(0.03 \mathrm{ml})$ were diluted to 0.07 $\mathrm{ml}$ by the addition of buffer $(0.01 \mathrm{M}$ Tris-hydrochloride [pH 8.0] and $0.001 \mathrm{M}$ EDTA) and mixed with 0.03 $\mathrm{ml}$ of Inman buffer $(4 \mathrm{ml}$ of $37 \%$ formaldehyde, 0.32 $\mathrm{ml}$ of $1 \mathrm{M} \mathrm{Na} \mathrm{CO}_{3}$, and $0.4 \mathrm{ml}$ of $0.126 \mathrm{M}$ EDTA) adjusted to $\mathrm{pH} 8.7$ with $\mathrm{HCl}$ prior to mixing. After incubation at $25^{\circ} \mathrm{C}$ for $10 \mathrm{~min}$, the samples were cooled in an ice bath for $5 \mathrm{~min}$ and mixed with an equal volume of formamide; aqueous cytochrome $c$ was added to a final concentration of $0.01 \%$. The samples were incubated for $10 \mathrm{~min}$ at $25^{\circ} \mathrm{C}$ before $0.005 \mathrm{ml}$ was spread onto the surface of a water droplet. The DNA was picked up on nitrocellulose-covered copper grids, rinsed in $95 \%$ ethanol, stained with uranyl acetate (6), rinsed in isopentane, and rotary shadowed with platinum at a $6^{\circ}$ angle. Micrographs were taken with a Siemens Elmiskop IA electron microscope at magnifications calibrated with a diffraction grating replica (Fullam 54,864 lines per inch).

\section{RESULTS}

Packaging of DNA synthesized by a T7 3,6 extract. To test the efficiency with which T7 DNA synthesized in vitro can be encapsulated into phage heads in vitro, a comparison was made between the accumulated DNA content in a DNA-synthesizing reaction mixture and the number of phage produced when portions of the same reaction mixtures were subsequently incubated in the presence of an extract capable of in vitro packaging. An extract was prepared from wild-type $E$. coli infected with T7 carrying amber mutations in genes 3 and 6 , two genes previously shown to be nonessential to in vitro DNA synthesis (15). T7 wild-type DNA was incubated with this extract under standard reaction conditions. Portions were withdrawn at intervals and assayed for DNA content and for ability to produce wild-type $\mathrm{T} 7$ phage when incubated in the standard in vitro packaging reaction under conditions that assured a linear dependence between phage production and DNA concentration (24). DNA synthesis was linear with time for up to $20 \mathrm{~min}$, and the number of phage produced in vitro also increased with the duration of the in vitro DNA synthesis reaction (Fig. 1). Since a suppressor-free host was used to plate the phage resulting from this procedure, any endogenous DNA present in the extracts used for either DNA synthesis or packaging could presumably not be expressed due to the presence of amber mutations. Although the wild-type DNA provided as template resulted in formation of phage particles even when no in vitro DNA synthesis occurred (zero incubation time), the fivefold increase in phage produced during the 30-min duration of the in vitro DNA synthesis reaction suggests the generation of a significant amount of biologically active DNA. 
To extend these observations, the newly synthesized DNA was separated from the exogenous template DNA. Purified wild-type density-labeled DNA was used as a template for in vitro DNA synthesis under conditions similar to those used for the experiment shown in Fig. 1. The product of the reaction was sedimented to equilibrium in an isopycnic gradient to yield the profile shown in Fig. 2. Fractions of this gradient corresponding to the fully heavy, fully light, and hybrid-density regions were pooled, dialyzed, and tested in an in vitro packaging reaction. The data in Table 1 clearly show that the DNA from the fully light and fully heavy regions of the gradient can be packaged in vitro with about the same efficiency; the DNA from the hybrid-density region showed a packaging efficiency about three- to fourfold higher. The significance of this difference is uncertain, but, as discussed below, an enrichment of complete T7 chromosomes in the hybrid-density pool may be responsible for higher phage production. However, these data demonstrate that the product of the in vitro DNA synthesis reaction can be encapsulated into phage particles with good efficiency. Results similar to these were obtained in several other experiments, including experiments performed with extracts that packaged the control DNA with somewhat different efficiencies.

Previous experiments by other workers showed high levels of in vitro recombination during packaging $(38,39,48)$. Because of endogenous DNA present in the extracts used for both
DNA synthesis and packaging, an appreciable level of in vitro recombination could affect the interpretation of experiments. The $\mathrm{T} 7_{3,5,6} \mathrm{mu}-$ tant used to prepare extracts for in vitro packaging in our experiments was chosen to minimize the level of endogenous DNA in the reaction and to reduce in vitro molecular recombination. Presumably, use of this mutant phage would also eliminate the presence of any actively replicating DNA in the extract used for packaging. Our earlier experiments (24) could not rule out the possibility that some recombination can occur in vitro. Thus, it could be true that some of the DNA present in the phage produced in these experiments originated as endogenous DNA into which wild-type copies of genes 3,5 , and 6 were introduced by in vitro recombination. To provide an estimate of the level of recombination during packaging, an attempt was made to package $\mathrm{T} 7$ with amber mutations in genes at various distances from genes 3,5 , and 6. DNA was purified from $\mathrm{T} 7$ with single amber mutations in genes $1,4,5$, and 19 , and the packaging efficiencies were compared with those of wild-type DNA under standard assay conditions. These data (Table 2) indicate that T7 DNA with amber mutations in gene 1,4 , or 19 is expressed at a level 300- to 1,000-fold lower than that for wildtype DNA after in vitro packaging and plating on suppressor-free indicator bacteria. The DNA with a mutation in gene 5 produced phage only at a level comparable to the wild-type contamination in the phage preparation from which the

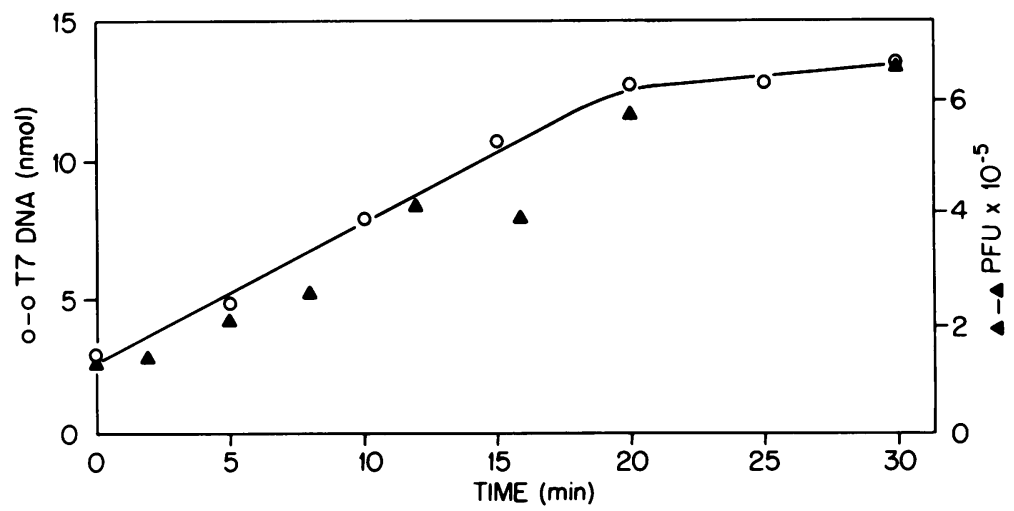

Fig. 1. Comparison of biological activity with amount of DNA synthesized in vitro. An extract prepared from strain W3110 infected with bacteriophage $T 7_{3,6}$ was incubated at $30^{\circ} \mathrm{C}$ with 30 nmol of wild-type T7DNA per $\mathrm{ml}$ of reaction mixture under conditions described in the text. $\left.{ }^{32} P\right] d A T P$ was present at $6.6 \mathrm{cpm} / \mathrm{pmol}$. At the indicated times, $0.1-\mathrm{ml}$ samples were removed and precipitated with $1 \mathrm{~N} \mathrm{HCl}-0.1 \mathrm{M}$ sodium pyrophosphate. Radioactivity was determined, and the amount of DNA synthesized was calculated. (O) Total amount of DNA present in a $0.1-\mathrm{ml}$ portion of the reaction mixture, including the 3 nmol of unlabeled DNA. Portions of $10 \mu l$ of the reaction mixture were diluted in $20 \mathrm{mM}$ Tris-hydrochloride ( $\mathrm{pH}$ 7.5) before incubation in the in vitro packaging system according to the procedure described earlier (24). ( $\triangle$ ) Average PFU present in $0.1 \mathrm{ml}$ of reaction mixture. Based on calculations of standard deviation, the expected experimental error associated with the determinations of phage produced in vitro was $\pm 45 \%$. 


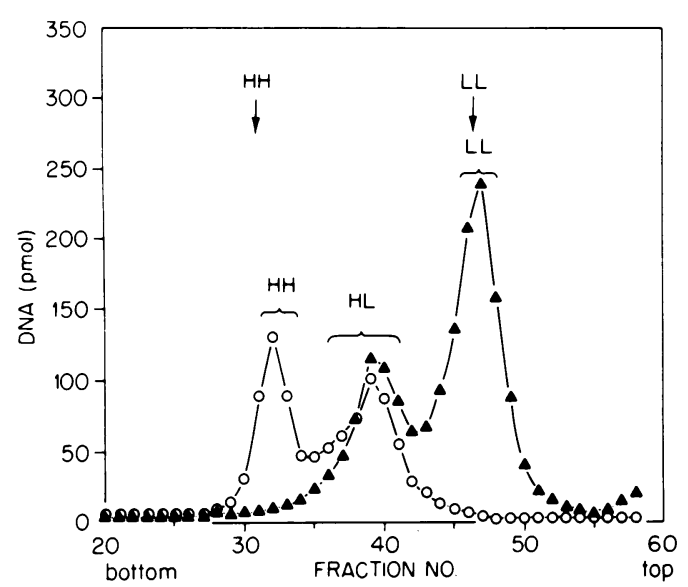

FIG. 2. Isopycnic analysis of DNA synthesized in vitro. A 0.5-ml DNA synthesis reaction mixture containing an extract of $T 7_{3,6}$-infected strain W3110 was incubated for $20 \mathrm{~min}$ at $30^{\circ} \mathrm{C}$ as described in the legend to Fig. 1. [ ${ }^{32}$ P]dATP was present at 9.7 $\mathrm{cpm} / \mathrm{pmol}$; the reaction contained $15 \mathrm{nmol}$ of $T 7$ wildtype ${ }^{3} H^{13} C^{15} N$-labeled DNA at $6 \mathrm{cpm} / \mathrm{pmol}$. The reaction was terminated by chilling the mixture and adding $0.05 \mathrm{ml}$ of $0.5 \mathrm{M} \mathrm{EDTA}$ and $1 \mathrm{ml}$ of NET buffer. The reaction mixture and enough $1 / 10$ concentration of NET buffer to make $6 \mathrm{~g}$ were added to 8.0 $\mathrm{g}$ of solid $\mathrm{CsCl}$. The gradient was spun in a Spinco Ti50 rotor in a model $L$ centrifuge at $20^{\circ} \mathrm{C}$ and 33,000 rpm for $60 \mathrm{~h}$; fractions were collected from a hole punctured in the bottom of the centrifuge tube. A 20 $\mu l$ sample of each fraction was removed and, after addition of $0.05 \mathrm{ml}$ of salmon sperm DNA at a concentration of $0.5 \mathrm{mg} / \mathrm{ml}$, was acid precipitated as described in the text. The radioactivity in each $20-\mu l$ sample was determined, and the amounts of ${ }^{3} \mathrm{H}$ - and ${ }^{32} \mathrm{P}$-labeled DNA were calculated; profiles are shown $\left(O,{ }^{3} \mathrm{H}^{13} \mathrm{C}^{15} \mathrm{~N}\right.$-labeled DNA; $\triangle{ }^{32}$ P-labeled DNA). The arrows labeled $H H$ and $L L$ indicate the peak positions of ${ }^{3} H^{13} C^{15} N$-labeled T7 DNA and ${ }^{14} C$-labeled T7 $D N A$ recovered from an identical $\mathrm{CsCl}$ gradient spun under the same conditions. Direction of sedimentation is right to left. The fractions of the gradient indicated by sets of brackets were pooled and di. alyzed against three changes of 2 liters of ice-cold 10 mM Tris-hydrochloride ( $p H$ 7.5)-0.1 mM EDTA under sterile conditions before use in the experiment detailed in Table 1.

DNA was extracted. The other values are higher than can be explained by experimental error or contamination with wild-type phage and may, in fact, be due to recombination. However, it is difficult to explain why the value obtained with the gene 4 mutant DNA is not much lower than that obtained with the DNAs mutant in either gene 1 or gene 19 , since rescue of gene 4 by the endogenous DNA from $T 7_{3,5,6}$ would require a double cross-over. Nevertheless, these data strongly suggest that although some in vitro recombination may occur in conjunction with in vitro packaging, the amount of recombination is too low to affect interpretation of experiments performed with the packaging system.

Using a system with larger amounts of endogenous DNA present, Sadowski reported little or no effect on recombination packaging when endogenous T7 DNA was broken by sonic disruption or treatment with a restriction endonuclease (38). Therefore, as an additional control, the effect of fragmentation of exogenous DNA on packaging efficiency was tested under our conditions by subjecting ${ }^{3} \mathrm{H}$-labeled T7 DNA to brief sonic disruption or to repeated passage through a hypodermic needle, then subjecting it to zone sedimentation through alkaline sucrose to yield an estimate of the average molecular weight of each preparation. The same DNA was incubated in the in vitro packaging system to determine its biological activity. Figure 3 shows that a fivefold reduction in average molecular weight caused a 1,000 -fold reduction in packaging efficiency. Sonically disrupted DNA showed a packaging efficiency below the limit of resolution of our measurements, i.e., less than $10^{-4}$ of the untreated control. Although these data do not necessarily provide a reliable determination of the exact functional dependence of packaging efficiency on DNA size, they clearly show that broken DNA is a very poor substrate for in vitro packaging.

Formation of fast-sedimenting DNA in vitro. The results presented above demonstrate in vitro assembly of complete phage particles by packaging DNA synthesized by extracts prepared from $T 7_{3,6}$-infected cells. Since the DNA made by these extracts is approximately the size of a complete T7 genome (29), it was of interest to see whether longer DNA molecules could be formed in vitro and to ask if these might also be biologically active. A reduced level of the gene 6 exonuclease interferes with in vivo T7 DNA replication (47) and diminishes the amount of in vivo and in vitro recombination $(21,32,38)$. Since this gene product appears important in concatemer formation, a process thought essential to normal T7 phage morphology (49), it was of interest to examine the T7 DNA synthesized in vitro in the presence of the gene 6 exonuclease. To achieve this, a T7 mutant deficient in gene 3 was chosen to reduce nonspecific endonuclease activity on the exogenous template (43) and in the hope of accumulating concatemeric DNA $(32,45)$.

First, we measured the kinetics of in vitro DNA synthesis performed by an extract prepared from strain $\mathrm{W} 3110$ infected with $\mathrm{T} 7_{3}$. The experiment (Fig. 4) demonstrated that DNA 
TABLE 1. Packaging efficiency of DNA recovered from in vitro DNA synthesis reaction ${ }^{a}$

\begin{tabular}{|c|c|c|c|c|c|c|c|}
\hline Expt & DNA & $\begin{array}{c}{\left[{ }^{3} \mathrm{H}\right] \mathrm{DNA}} \\
\text { (pmol) }\end{array}$ & $\begin{array}{l}\text { [pmol) } \\
\text { (pmDNA }\end{array}$ & $\begin{array}{c}\text { Total } \\
\text { DNA } \\
\text { (pmol) }\end{array}$ & $\begin{array}{l}\text { Infective cen- } \\
\text { ters }\end{array}$ & Percent efficiency & $\begin{array}{l}\text { Relative } \\
\text { packaging } \\
\text { efficiency }\end{array}$ \\
\hline \multirow[t]{4}{*}{1} & $\begin{array}{c}\text { Untreated } \\
\text { control }\end{array}$ & & & 27 & 6,600 & $3.2 \times 10^{-3}( \pm 25 \%)$ & 1.00 \\
\hline & HH & 51 & 5 & 56 & 3,200 & $0.8 \times 10^{-3}( \pm 35 \%)$ & 0.25 \\
\hline & $\mathrm{HL}$ & 41 & 33 & 74 & 24,500 & $4.4 \times 10^{-3}( \pm 35 \%)$ & 1.38 \\
\hline & LL & 2 & 69 & 71 & 6,600 & $1.2 \times 10^{-3}( \pm 25 \%)$ & 0.38 \\
\hline \multirow[t]{4}{*}{2} & $\begin{array}{l}\text { Untreated } \\
\text { control }\end{array}$ & & & 10 & 31,000 & $4.1 \times 10^{-2}( \pm 35 \%)$ & 1.00 \\
\hline & $\mathrm{HH}$ & 19 & 2 & 21 & 31,300 & $1.9 \times 10^{-2}( \pm 15 \%)$ & 0.46 \\
\hline & $\mathrm{HL}$ & 32 & 25 & 57 & 320,000 & $7.3 \times 10^{-2}( \pm 20 \%)$ & 1.78 \\
\hline & LL & 3 & 47 & 50 & 100,000 & $2.7 \times 10^{-2}( \pm 20 \%)$ & 0.66 \\
\hline
\end{tabular}

${ }^{a}$ Samples of $10 \mu \mathrm{l}$ from the pooled fractions of $\mathrm{CsCl}$ gradients were diluted and incubated for $60 \mathrm{~min}$ in an in vitro packaging reaction using an extract prepared from strain W3110 infected with T7 with amber mutations in genes 3,5 , and 6 under the standard assay conditions previously described (24). The resulting phage were plated using strain W3110 as indicator bacteria. Samples of each pool were also acid precipitated to determine the amounts of template $\left({ }^{3} \mathrm{H}\right)$ and product $\left({ }^{32} \mathrm{P}\right)$ DNA present in $10 \mu$ l. The untreated control consisted of purified T7 DNA packaged under identical conditions. HH, HL, and LL refer to fully heavy, hybrid-density, and fully light regions of the gradients. Experiment 1 shows results from the gradient in Fig. 2. Experiment 2 was carried out the same way except that different extracts were used for DNA synthesis and DNA packaging. In all tables, the expected percentage errors (shown in parentheses) reflect standard deviations.

TABLE 2. Efficiencies of packaging mutant DNAs ${ }^{a}$

\begin{tabular}{|c|c|c|c|c|c|}
\hline DNA & $\begin{array}{c}\text { Amt of DNA } \\
\text { (nmol) }\end{array}$ & PFU & Percent efficiency & $\begin{array}{l}\text { Average \% effi- } \\
\text { ciency }\end{array}$ & $\begin{array}{c}\text { Relative packaging } \\
\text { efficiency }\end{array}$ \\
\hline \multirow[t]{2}{*}{ Wild type } & 0.01 & 32,917 & $4.39 \times 10^{-2}( \pm 25 \%)$ & \multirow{2}{*}{$3.63 \times 10^{-2}$} & \multirow{2}{*}{1.00} \\
\hline & 0.10 & 214,833 & $2.86 \times 10^{-2}( \pm 15 \%)$ & & \\
\hline \multirow[t]{2}{*}{$\mathbf{T} 7_{1}$} & 0.10 & 517 & $6.89 \times 10^{-5}( \pm 30 \%)$ & \multirow{2}{*}{$8.27 \times 10^{-5}$} & \multirow{2}{*}{$2.28 \times 10^{-3}$} \\
\hline & 0.25 & 1,810 & $9.65 \times 10^{-5}( \pm 20 \%)$ & & \\
\hline \multirow[t]{2}{*}{$\mathrm{T} 7_{4}$} & 0.10 & 420 & $5.60 \times 10^{-5}( \pm 20 \%)$ & \multirow{2}{*}{$5.76 \times 10^{-5}$} & \multirow{2}{*}{$1.59 \times 10^{-3}$} \\
\hline & 0.25 & 1,108 & $5.91 \times 10^{-5}( \pm 20 \%)$ & & \\
\hline \multirow[t]{2}{*}{$\mathrm{T} 7_{19}$} & 0.10 & 323 & $4.31 \times 10^{-5}( \pm 20 \%)$ & \multirow{2}{*}{$3.50 \times 10^{-5}$} & \multirow{2}{*}{$9.64 \times 10^{-4}$} \\
\hline & 0.25 & 503 & $2.68 \times 10^{-5}( \pm 30 \%)$ & & \\
\hline \multirow[t]{2}{*}{$\mathrm{T} 7_{5}$} & 0.25 & 20 & $1.07 \times 10^{-6}( \pm 120 \%)$ & \multirow{2}{*}{$9.19 \times 10^{-7}$} & \multirow{2}{*}{$2.53 \times 10^{-5}$} \\
\hline & 0.50 & 29 & $7.67 \times 10^{-7}( \pm 85 \%)$ & & \\
\hline
\end{tabular}

${ }^{a}$ DNA extracted from $\mathrm{T} 7$ wild-type, $\mathrm{T} 7_{1}, \mathrm{~T} 7_{4}, \mathrm{~T} 7_{19}$, or $\mathrm{T} 7_{5}$ phage was diluted in $10 \mathrm{mM}$ Tris-hydrochloride (pH 7.5); the amounts of DNA shown were packaged using identical reaction mixtures and an extract prepared from strain $\mathrm{W} 3110$ infected with $\mathrm{T} 7_{3,5,6}$. The resulting phage were plated using strain $\mathrm{W} 3110$ to give the indicated values of PFU. The ratio of wild-type to T7 $7_{1}$ phage in the preparation used for T7 $7_{1} \mathrm{DNA}$ was $2 \times 10^{-4}$; this ratio for $\mathrm{T} 7_{4}$ DNA was $2 \times 10^{-5}$; for T7 $7_{19}$ DNA, $1 \times 10^{-4}$; and for T7 $7_{5} \mathrm{DNA}, 4 \times 10^{-5}$; these ratios were determined by comparing plating efficiencies on strains W3110 and 011'.

synthesis is linear with time for about $20 \mathrm{~min}$ and is dependent upon exogenous DNA. The DNA synthesized by extracts prepared from $\mathrm{T} 7_{3}$ was characterized by zone sedimentation through alkaline and neutral sucrose and by isopycnic sedimentation. An extract was prepared from strain W3110 infected with $T 7_{3}$ and used in an in vitro DNA synthesis reaction. Samples were withdrawn at intervals and subjected to sedimentation through neutral sucrose. Sedimentation conditions that placed unitlength T7 DNA $1 / 3$ from the bottom of the gradient pelleted both the product and template DNA from the in vitro reaction to the bottom of the gradient (data not shown). The data in Fig.
5 show that the size distribution of both the template and product DNA is quite heterogeneous and that most of the DNA recovered from the in vitro reaction sediments more rapidly than intact T7 chromosomes. In fact, some of this DNA has a sedimentation coefficient of about $400 \mathrm{~S}$. For comparison, DNA recovered from an in vitro DNA synthesis reaction using an extract from $\mathrm{T} 7_{3,6}$-infected cells was sedimented at a higher speed and for a longer time through neutral sucrose to yield the data in Fig. 6. As previously reported (29), most of the DNA synthesized in a reaction of this type has nearly the same molecular weight as an intact $\mathrm{T} 7 \mathrm{chro-}$ mosome. The DNA recovered from an in vitro 


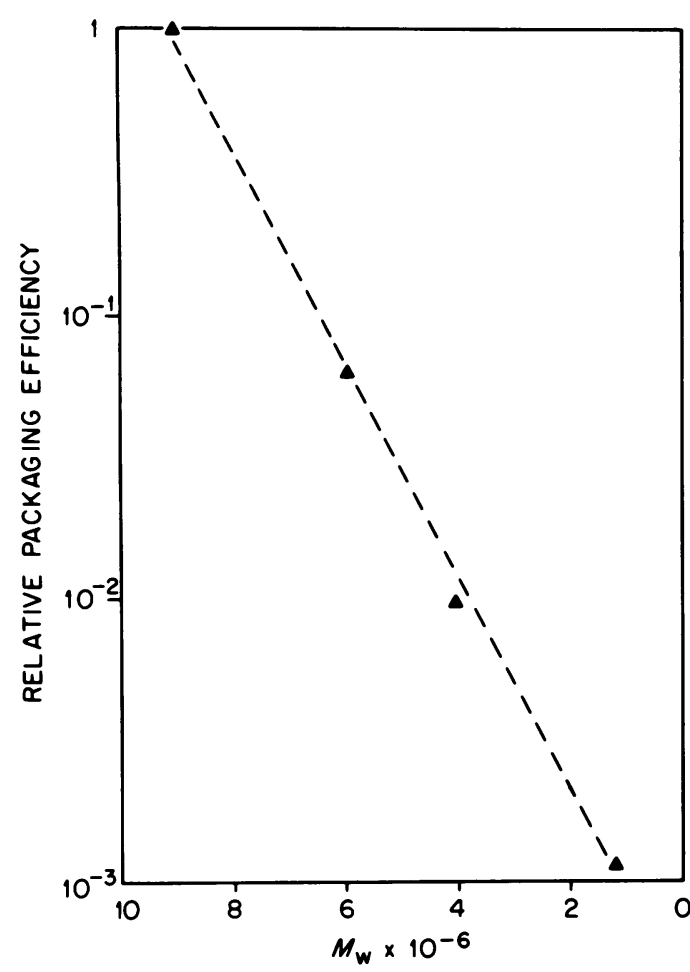

Fig. 3. Effect of size of DNA on packaging efficiency. Three 0.3-ml portions of ${ }^{3} \mathrm{H}$-labeled T7 DNA were fragmented by repeated passages through a 27 . gauge syringe needle or by sonic disruption for 1 s at maximum output with a power setting of 40 using the microtip of a Bronwill Biosonik sonicator. A 10- $\mu$ l sample of each portion was diluted into $0.09 \mathrm{ml}$ of 10 mM Tris-hydrochloride (pH 7.5)-0.1 mM EDTA, layered on top of a linear 5 to 20\% alkaline sucrose gradient, and spun at $49,000 \mathrm{rpm}$ at $20^{\circ} \mathrm{C}$ in a Spinco $S W 56$ rotor for $120 \mathrm{~min}$. Fractions were pumped from the bottom of the tube and collected on paper strips. DNA was precipitated by immersing the paper strips in $5 \% \mathrm{Cl}_{3} \mathrm{COOH}$ at $22^{\circ} \mathrm{C}$ for $15 \mathrm{~min}$; the strips were then washed twice in ethanol, dried, and counted in toluene-based counting solution. Weight-average molecular weights were calculated according to Char lesby (3, 5, 9). Fragmented and intact DNAs were incubated under standard conditions for in vitro packaging, with strain W3110 as indicator. Packaging efficiencies of the fragmented DNAs relative to intact DNA were calculated; the average for virion DNA was $0.10 \%$.

DNA synthesis reaction using an extract prepared from $\mathrm{T} 7_{3}$ was also sedimented through alkaline sucrose to yield the profiles in Fig. 7. These data show that both the product and template DNA are somewhat more heterogeneous in size than the DNA recovered from in vitro reactions using extracts prepared with $T 7_{3,6}$ (29) and suggest that at least some of the DNA

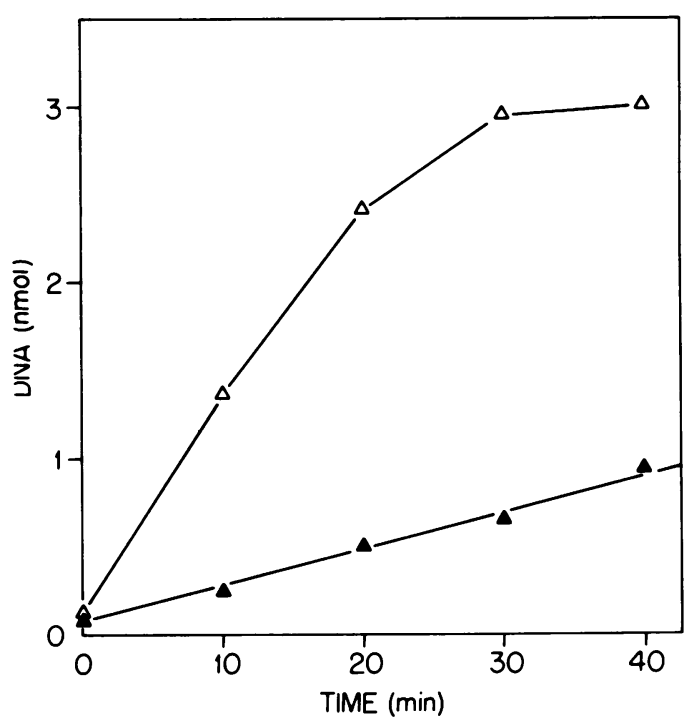

FiG. 4. Kinetics of DNA synthesis in a T7 extract. An extract prepared from $\mathrm{T}_{3}$-infected strain W3110 was incubated at $30^{\circ} \mathrm{C}$ in the presence and absence of wild-type T7 DNA under standard conditions for DNA synthesis. [ $\left.{ }^{32} P\right] d A T P$ was present at $2.6 \mathrm{cpm} / \mathrm{pmol}$. At the indicated times, $0.1-\mathrm{ml}$ samples were removed and acid precipitated, radioactivity was determined, and the amount of DNA synthesized was calculated. Amounts of DNA synthesized per 0.1 $\mathrm{ml}$ sample in the presence $(\Delta)$ and absence $(\Delta)$ of exogenous T7 DNA are shown.

recovered from the experiment described in Fig. 7 is of greater single-strand molecular weight than intact T7 DNA. Also, it is clear from Fig. 7 that the rapidly sedimenting structures seen in Fig. 5 no longer exist after alkaline denaturation, suggesting that hydrogen bonding may play a part in the formation of these structures. Experiments similar to the ones shown in Fig. 5, 6, and 7 , carried out using a $\operatorname{rec} A$ derivative of strain W3110, have yielded similar results, indicating that the host's recA-dependent recombination system plays no essential role in the formation of these rapidly sedimenting structures (data not shown).

Experiments with extracts from $\mathrm{T} 7_{3}$-infected cells were also performed with density-labeled DNA as template. DNA recovered from in vitro DNA synthesis reactions was sedimented to equilibrium in $\mathrm{CsCl}$ gradients (Fig. 8). In contrast to experiments using extracts prepared from $\mathrm{T}_{3,6}$-infected bacteria (Fig. 2), the $\mathrm{CsCl}$ gradients containing DNA recovered after in vitro DNA synthesis performed by extracts from $\mathrm{T} 7_{3}$-infected cells revealed poor separation of the ${ }^{3} \mathrm{H}$-labeled template DNA and the ${ }^{32} \mathrm{P}$-labeled product; most of the DNA was at a density intermediate between fully heavy and fully light. 


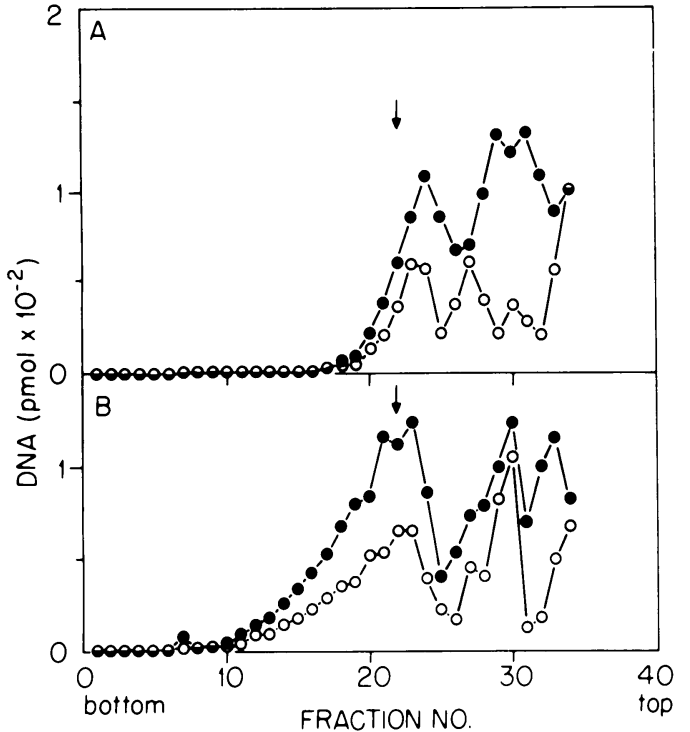

FIG. 5. Characterization of fast-sedimenting DNA by zonal centrifugation on neutral sucrose gradients. An extract prepared from $T 7_{3}$-infected strain W3110 was incubated with $30 \mathrm{nmol}$ of ${ }^{3} \mathrm{H}$-labeled T7 DNA per $m l$ of standard in vitro DNA synthesis reaction mixture; [ $\left.{ }^{32} P\right] d A T P$ was present at $8.5 \mathrm{cpm} / \mathrm{pmol}$. After 20-(A) and 40-min (B) intervals, 0.1-ml samples were removed, and the reactions were terminated by addition of EDTA. Samples were incubated with Sarkosyl, and 0.1-ml portions were layered onto linear 5 to $20 \%$ neutral sucrose gradients with a 0.2-ml $84 \%$ sucrose shelf. Centrifugation in a Spinco SW56 rotor was for $35 \mathrm{~min}$ at $17,500 \mathrm{rpm}$ and $20^{\circ} \mathrm{C}$. Fractions were pumped from the bottom of the tube and, after addition of $0.05 \mathrm{ml}$ of salmon sperm DNA at a concentration of $0.5 \mathrm{mg} / \mathrm{ml}$, were acid precipitated, filtered, and counted; profiles are shown $\left(O,{ }^{3} \mathrm{H}\right.$-template; ${ }^{32}$ P.product). The arrow indicates the position of intact ${ }^{3} \mathrm{H}$-labeled T7 phage (450S) after sedimentation under identical conditions.

With longer reaction times, the buoyant density of the ${ }^{3} \mathrm{H}$ - and ${ }^{32} \mathrm{P}$-labeled DNA gradually decreased, and some separation of the ${ }^{32} \mathrm{P}$-labeled product toward lighter density could be seen (Fig. 8). These profiles indicate that after $20 \mathrm{~min}$ of synthesis the ratio of ${ }^{32} \mathrm{P}$-labeled DNA to ${ }^{3} \mathrm{H}$ labeled DNA is greater than unity and that most of the ${ }^{32} \mathrm{P}$-labeled product remains attached to the heavy-density ${ }^{3} \mathrm{H}$-labeled template. In most experiments, a separate peak of DNA was observed near the top of the gradient. The ratio of ${ }^{32} \mathrm{P}$ to ${ }^{3} \mathrm{H}$ in this light-density region was about the same as it was for the major peak of DNA. When the fractions from the top of a $\mathrm{CsCl}$ gradient, like the ones in Fig. 8, were dialyzed, treated with protease $\mathrm{K}$, and subjected to a second isopycnic gradient analysis, the labeled material originally near the top of the gradient

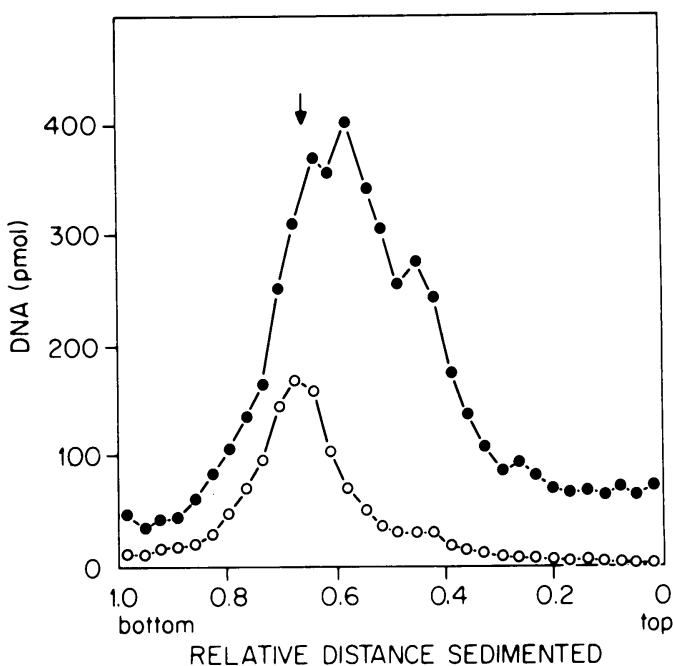

FIG. 6. Characterization by zonal centrifugation on neutral sucrose gradients of DNA synthesized in vitro by use of a T7 $7_{3,6}$-infected extract. An extract prepared from $T 7_{3.6}$-infected strain W3110 was incubated for $40 \mathrm{~min}$ with $30 \mathrm{nmol}$ of ${ }^{3} \mathrm{H}$-labeled T7 DNA per $m l$ of standard in vitro DNA synthesis reaction mixture; $\left[{ }^{32} P\right] d A T P$ was present at $3.6 \mathrm{cpm} / \mathrm{pmol}$. The reaction was terminated by addition of EDTA to a concentration of $50 \mathrm{mM}$. After incubation with Sarkosyl, a 0.1-ml portion was layered onto a linear 5 to $20 \%$ neutral sucrose gradient with a $0.2-\mathrm{ml} 84 \%$ sucrose shelf. Centrifugation in a Spinco $S W 56$ rotor was for $120 \mathrm{~min}$ at $49,000 \mathrm{rpm}$ and $20^{\circ} \mathrm{C}$. Fractions were collected, and their radioactivity was determined as described in the legend to Fig. 5; profiles are shown $\left(\bigcirc,{ }^{3} \mathrm{H}\right.$-template;,${ }^{32} \mathrm{P}$-product $)$. The arrow indicates the position of intact T7 DNA.

was found at the same position as the major peak of DNA, i.e., at a position intermediate between fully heavy and fully light (data not shown). This suggests protein attachment to the DNA. In experiments in which DNA synthesized in vitro by extracts prepared from $\mathrm{T} 7_{3,6}$-infected cells was subjected to isopycnic analysis, significant amounts of labeled material of very light density were not observed.

Portions of the DNA synthesized by extracts prepared from $\mathrm{T}_{3}$-infected cells were also sedimented to equilibrium in alkaline $\mathrm{CsCl}$. This resulted (Fig. 9) in a separation of the ${ }^{32} \mathrm{P}$-labeled product from the ${ }^{3} \mathrm{H}$-labeled template. However, the shapes of the peaks of radioactivity recovered from this gradient (and others like it) suggest some covalent attachment between the ${ }^{3} \mathrm{H}$ - and ${ }^{32} \mathrm{P}$-labeled DNAs.

Electron microscopy of DNA synthesized in vitro. An experiment like the one described in Fig. 8 was performed; after $40 \mathrm{~min}$ of in vitro DNA synthesis, the reaction was stopped and the DNA was sedimented to equilibrium 


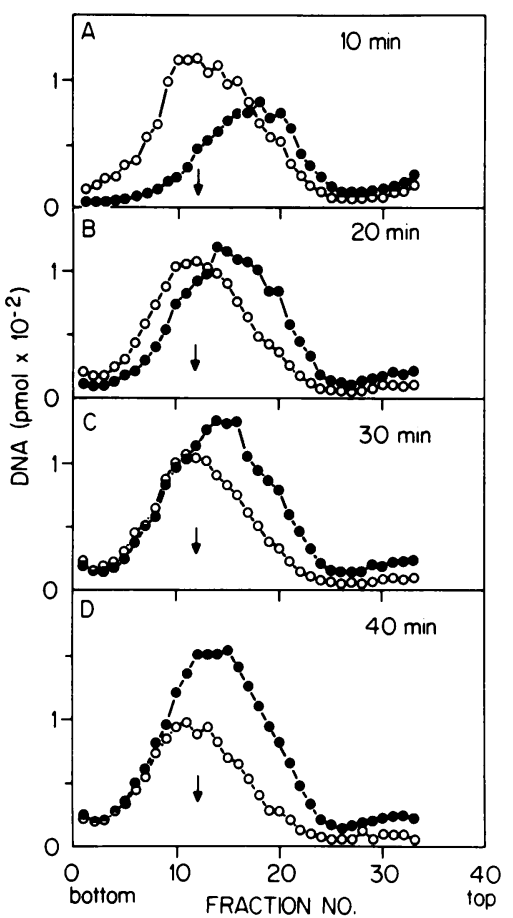

Fig. 7. Characterization by zonal centrifugation on alkaline sucrose gradients of DNA synthesized by a $T 7_{3}$-infected extract. An extract prepared from $T 7_{3^{-}}$infected strain W3110 was incubated with 30 nmol of ${ }^{3} \mathrm{H}$-labeled T7 DNA per ml of standard in vitro DNA synthesis reaction mixture; $\left[{ }^{32} P\right] d A T P$ was present at $12.0 \mathrm{cpm} / \mathrm{pmol}$. At 10-min intervals, $0.1-\mathrm{ml}$ samples were removed, and the reactions were terminated by addition of EDTA to a concentration of $50 \mathrm{mM}$. Samples were incubated with Sarkosyl, and 0.1-ml portions were layered onto linear 5 to $20 \%$ alkaline sucrose gradients. Centrifugation in a Spinco SW56 rotor was for $120 \mathrm{~min}$ at $49,000 \mathrm{rpm}$ and $20^{\circ} \mathrm{C}$. Fractions were collected and radioactivity determined as detailed in the legend to Fig. 5; profiles are shown $\left(\mathrm{O},{ }^{3} \mathrm{H}\right.$-template;,${ }^{32} \mathrm{P}$-product $)$.

through neutral $\mathrm{CsCl}$. Samples of each fraction from the gradient were acid precipitated, and their radioactivity was determined. The profile obtained closely resembled that in Fig. 8D. Those fractions that contained the major peak of DNA were pooled, dialyzed, and examined under the electron microscope. Many long, intricate DNA molecules were present, many of which appeared to be longer than intact $\mathrm{T} 7$ chromosomes (Fig. 10A). A higher magnification of selected areas (Fig. 10B and C) showed many branched and forked molecules. Extracting the DNA with phenol did not eliminate the complex structures (Fig. 11). In contrast, experiments performed with extracts from $\mathrm{T} 7_{3,6}$-infected bacteria yielded only DNA molecules shorter than or about the same length as complete T7 chro-

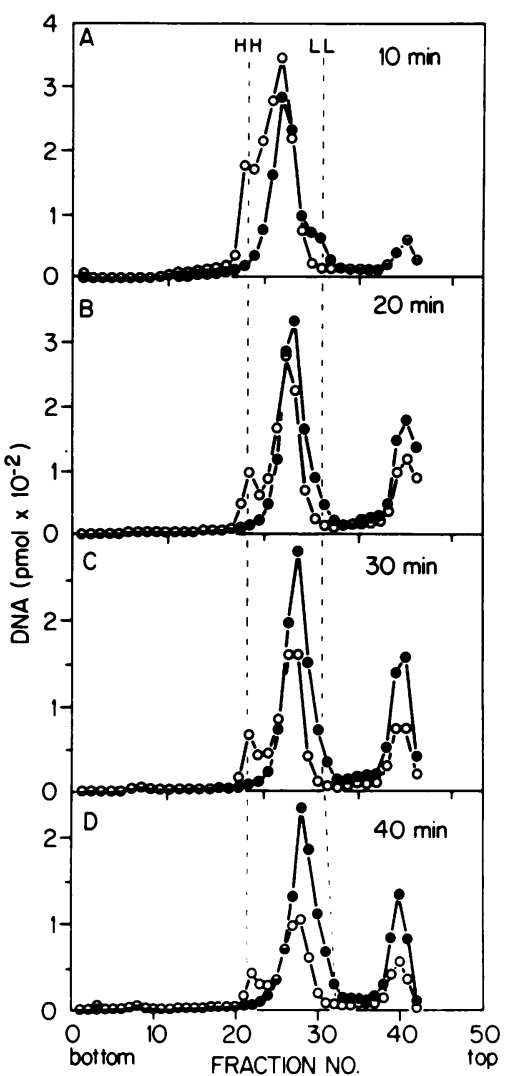

FIG. 8. Isopycnic gradient analysis of fast-sedimenting DNA. Four identical 0.2-ml DNA synthesis reaction mixtures containing an extract of $T 7_{3}$-infected strain W3110 were incubated at $30^{\circ} \mathrm{C}$. Each reaction mixture contained $6 \mathrm{nmol}$ of T7 wild-type ${ }^{3} \mathrm{H}^{13} \mathrm{C}^{15} \mathrm{~N}$-labeled DNA at $8.5 \mathrm{cpm} / \mathrm{pmol} ;\left[^{32} P\right] d A T P$ was present at $13.2 \mathrm{cpm} / \mathrm{pmol}$. The reactions were terminated at 10-min intervals by addition of EDTA and NET buffer; the reaction mixtures and 1/10 concentration of NET buffer were added to solid $\mathrm{CsCl}$. The gradients were spun in a Spinco Ti50 rotor at 37,000 rpm for $40 \mathrm{~h}$ at $20^{\circ} \mathrm{C}$; fractions (approximately $0.2 \mathrm{ml}$ ) were collected from a hole punctured in the bottom of the centrifuge tube, and refractive indexes were measured. Samples of $0.1 \mathrm{ml}$ of each fraction were removed, acid precipitated, and counted as described in the legend to Fig. 2; profiles are shown $\left(O,{ }^{3} \mathrm{H}^{13} \mathrm{C}^{15} \mathrm{~N}\right.$-labeled DNA;,${ }^{32} \mathrm{P}$-labeled DNA). The lines indicate the peak positions of ${ }^{3} H^{13} C^{15} N$-labeled T7 DNA and ${ }^{14} C$-labeled T7 DNA recovered from an identical $\mathrm{CsCl}$ gradient spun under the same conditions.

mosomes. These electron micrographs (not shown) frequently displayed what appear to be replication forks on the DNA molecules; however, intricate structures like the ones in Fig. $10 \mathrm{~A}$ or Fig. 11 were never observed after DNA synthesis by $\mathrm{T} 7_{3,6}$ extracts.

Biological activity of fast-sedimenting 
DNA. To examine the biological activity of the intricate structures in Fig. 10, we synthesized DNA in vitro by use of an extract from $T 7_{3}$ infected bacteria and density-labeled T7 DNA as a template. After isopycnic sedimentation in neutral $\mathrm{CsCl}$, the DNA from the major peak in the gradient was dialyzed and tested for biological activity along with a sample of the untreated density-labeled DNA used as template. Table 3 shows that the DNA recovered from the $\mathrm{CsCl}$ gradient was packaged with an efficiency more than 14-fold greater than the control (purified DNA not included in the DNA synthesis reaction). Several such experiments were performed, and although some variation was noticed among the experiments, in every case the DNA recovered after in vitro synthesis by an extract prepared from $\mathrm{T}_{3}$-infected cells was packaged with an efficiency from 10 to 50 times greater than that of the control DNA. When DNA from such an experiment was recovered from a $\mathrm{CsCl}$ gradient and a portion was extracted with phenol and dialyzed, it was found that removal of protein did not significantly affect the efficiency with which this DNA could be encapsulated into phage heads in vitro. An experiment was also performed with an extract prepared from $\mathrm{T} 7_{3^{-}}$ infected strain W3110 in the absence of exogenous DNA. When DNA recovered from the normal-density region of a $\mathrm{CsCl}$ gradient (which contains endogenous $\mathrm{T} 7_{3}$ DNA and DNA copied from endogenous template) was incubated in the in vitro packaging system and phage production was measured with a suppressor-free indicator strain, a negligible number of plaques (less than $10^{-5}$ of the control containing exogenous wildtype DNA) were found.

To provide direct comparison between the

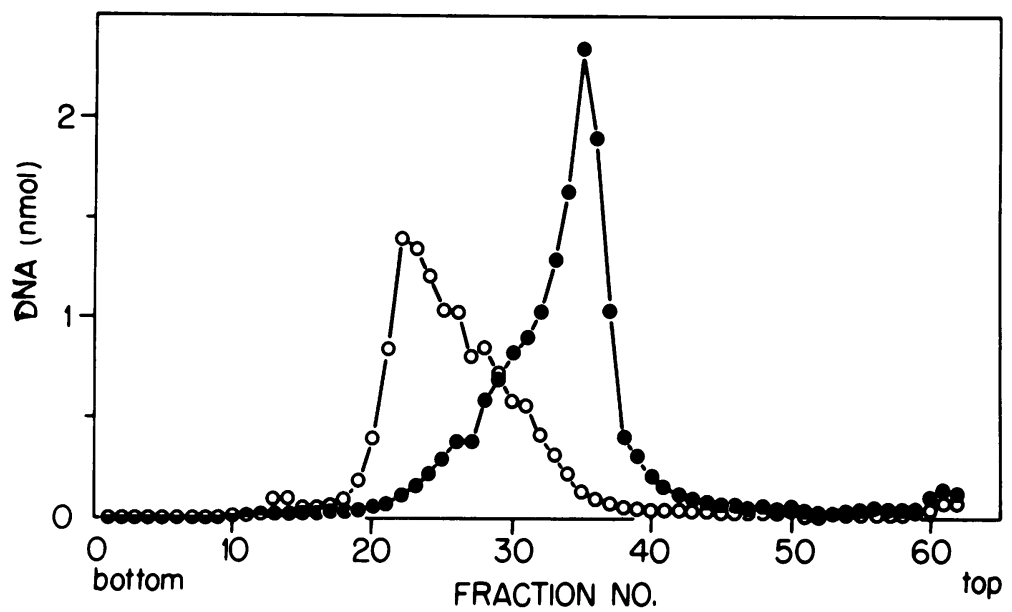

Fig. 9. Isopycnic analysis of fast-sedimenting DNA in alkaline CsCl gradient. A 0.6-ml DNA synthesis reaction mixture containing an extract of $T 7_{3}$-infected strain W3110 was incubated for 40 min at $30^{\circ} \mathrm{C}$. The reaction mixture contained $18 \mathrm{nmol}$ of $T 7$ wild-type ${ }^{3} \mathrm{H}^{13} \mathrm{C}^{15} \mathrm{~N}$-labeled DNA at $\left.8.5 \mathrm{cpm} / \mathrm{pmol} ;{ }^{32} \mathrm{P}\right] d A T P$ was present at $15.6 \mathrm{cpm} / \mathrm{pmol}$. The reaction was terminated by the addition of $0.06 \mathrm{ml}$ of $0.5 \mathrm{M} \mathrm{EDTA}$ and $0.4 \mathrm{ml}$ of ice-cold NET buffer; DNA was denatured by addition of $0.7 \mathrm{ml}$ of potassium phosphate buffer (pH 12.0 at $50 \mathrm{mM}$ ). The sample and sufficient 1/10 concentration of NET buffer were added to solid CsCl. The gradient was spun in a Spinco Ti50 rotor at 37,000 rpm for $40 \mathrm{~h}$ at $20^{\circ} \mathrm{C}$; fractions (approximately $0.12 \mathrm{ml}$ ) were collected from a hole punctured in the bottom of the centrifuge tube. Carrier DNA was added to the fractions, which then were acid precipitated and filtered before their radioactivity was determined as described in the legend to Fig. 2; profiles are shown $\left(0,{ }^{3} \mathrm{H}^{13} \mathrm{C}^{15} \mathrm{~N}\right.$-labeled DNA;,${ }^{32} \mathrm{P}$-labeled DNA).

TABLE 3. Biological activity of fast-sedimenting $D N A^{a}$

\begin{tabular}{lcccccc}
\hline Sample & $\begin{array}{c}\left.{ }^{3} \mathrm{H}\right] \mathrm{DNA} \\
(\mathrm{pmol})\end{array}$ & $\begin{array}{c}\left.{ }^{32} \mathrm{P}\right] \mathrm{DNA} \\
(\mathrm{pmol})\end{array}$ & $\begin{array}{c}\text { Total DNA } \\
(\mathrm{pmol})\end{array}$ & $\begin{array}{c}\text { Infective cen- } \\
\text { ters }\end{array}$ & Percent efficiency & $\begin{array}{c}\text { Relative ef- } \\
\text { ficiency }\end{array}$ \\
\hline $\mathrm{T} 7_{3}$ & 0.83 & 0.96 & 1.79 & 39,800 & $3.0 \times 10^{-1}( \pm 45 \%)$ & 14.3 \\
Control & 10 & 0 & 10 & 13,410 & $1.8 \times 10^{-2}( \pm 35 \%)$ & \\
Control & 100 & 0 & 100 & 177,400 & $2.4 \times 10^{-2}( \pm 20 \%)$ & \\
\hline
\end{tabular}

${ }^{a}$ A $10-\mu$ l portion of the DNA described in the legend to Fig. 10 was incubated in the in vitro packaging system previously described, as was ${ }^{3} \mathrm{H}^{13} \mathrm{C}^{15} \mathrm{~N}$-labeled T7 wild-type DNA, which served as the control. The resulting phage were plated using strain W3110 as indicator to give the number of infective centers. 

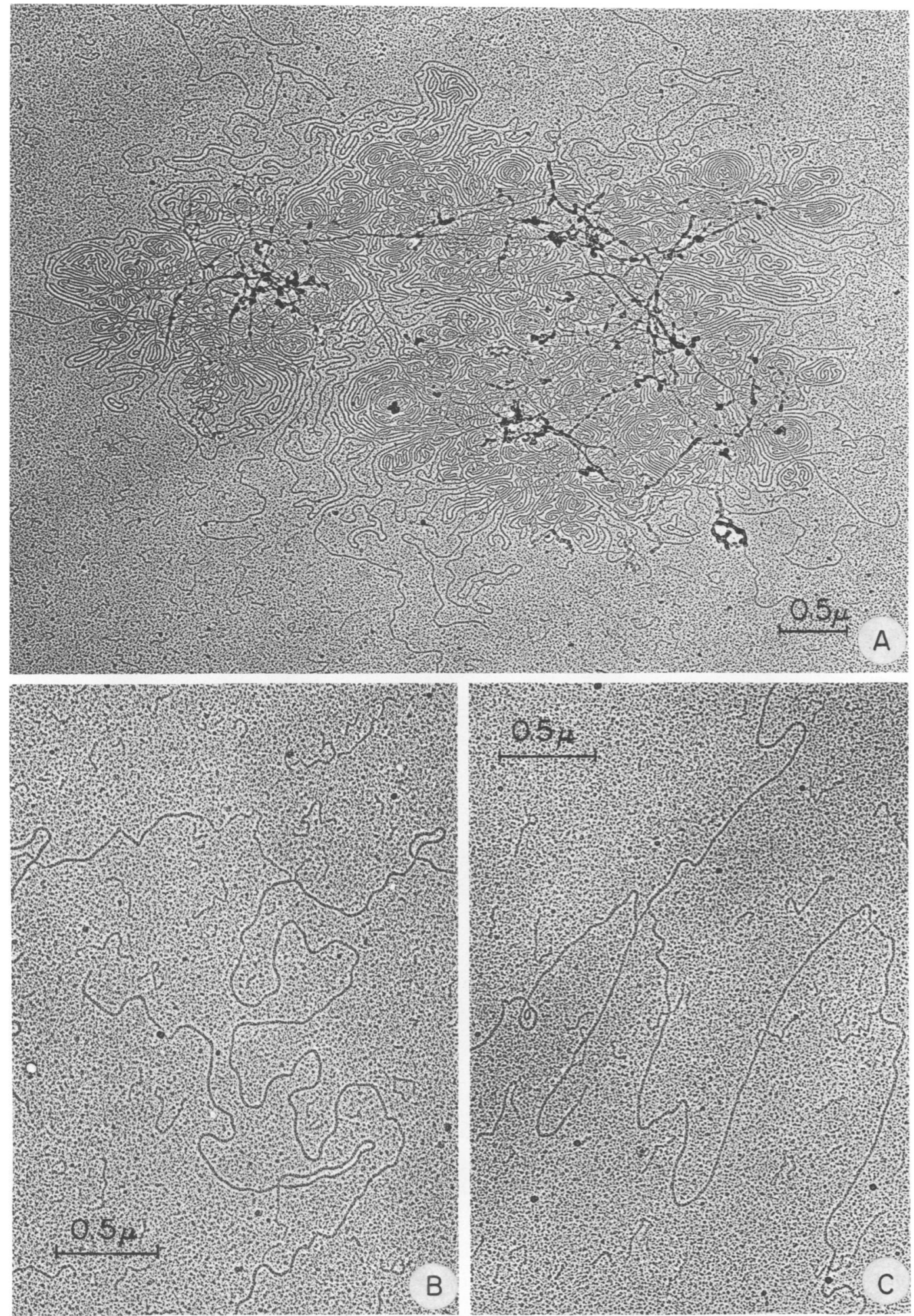

Fig. 10. Electron micrographs of fast-sedimenting DNA. The fractions of a gradient corresponding to fractions 27 to 29 in Fig. $8 D$ were pooled and dialyzed against two changes of 2 liters of $10 \mathrm{mM}$ Trishydrochloride ( $p H$ 7.5)-0.1 mM EDTA. The sample was prepared for electron micrography as described in the text. The bar represents a length of $0.5 \mu \mathrm{m}$. 
J. VIROL.

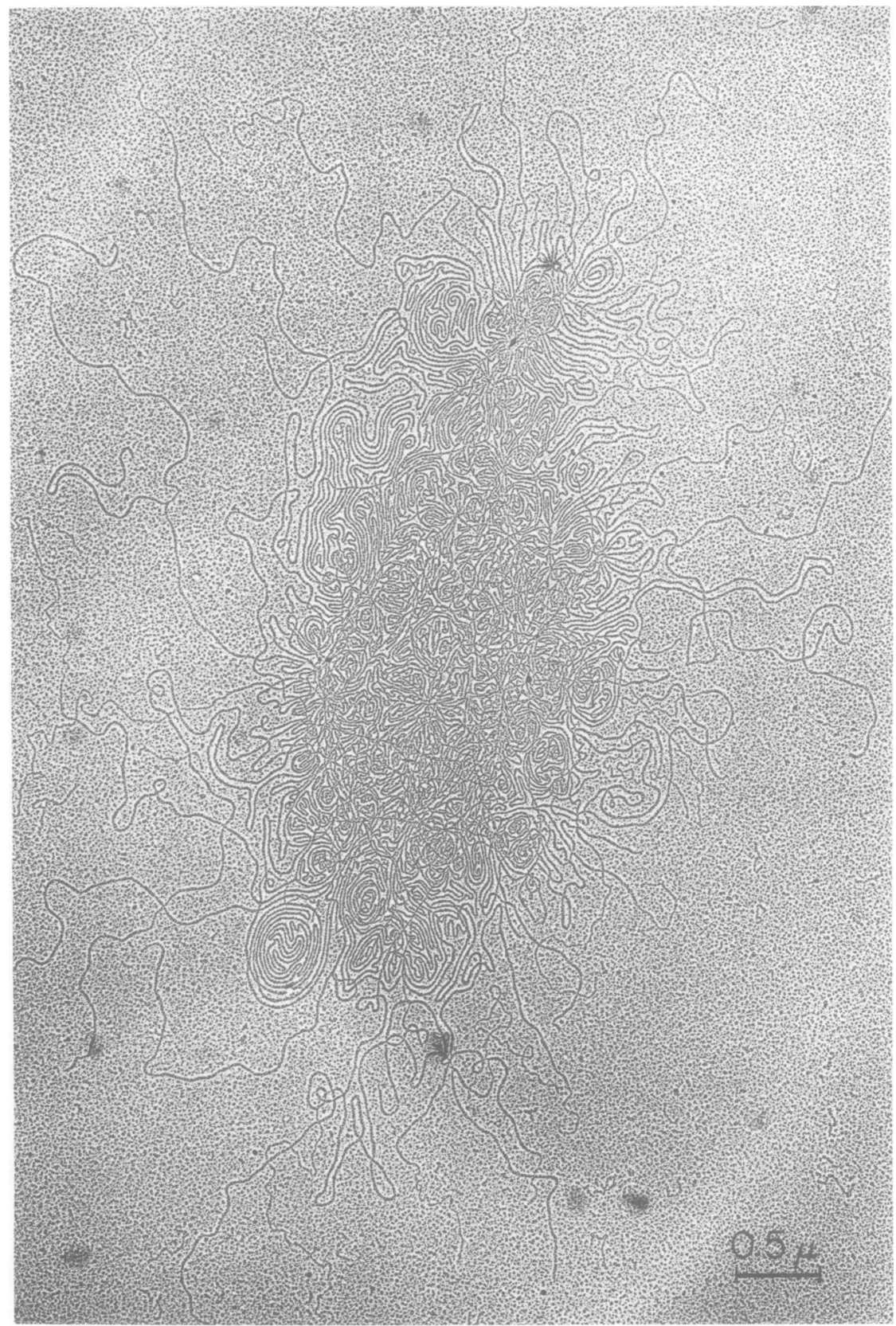

FIG. 11. Electron micrograph of phenol-extracted fast-sedimenting DNA. A portion of the sample described in the legend to Fig. 10 was extracted with redistilled phenol equilibrated with $0.05 \mathrm{M}$ phosphate buffer (pH 7.4). After dialysis, the sample was prepared for electron micrography as described in the text. The bar represents a length of $0.5 \mu \mathrm{m}$.

products of DNA synthesis carried out by extracts of $\mathrm{T} 7_{3^{-}}$and $\mathrm{T} 7_{3,6}$-infected $E$. coli, the experiment described in Table 4 was undertaken. After $20 \mathrm{~min}$ of in vitro DNA synthesis by extracts of bacteria infected with either $\mathrm{T} 7_{3}$ or $\mathrm{T} 7_{3,6}$, the DNA was sedimented in neutral $\mathrm{CsCl}$ and samples of the gradients were acid precipitated to yield profiles similar to those shown in Fig. 2 and 8B. The fully heavy, fully light, and hybrid-density DNAs recovered from 
TABLE 4. Comparison of biological activities of T7 DNAs synthesized in vitro ${ }^{a}$

\begin{tabular}{lcccccc}
\hline Sample & $\begin{array}{c}{\left[{ }^{3} \mathrm{H}\right] \mathrm{DNA}} \\
(\mathrm{pmol})\end{array}$ & $\begin{array}{c}\left.{ }^{32} \mathrm{P}\right] \mathrm{DNA} \\
(\mathrm{pmol})\end{array}$ & $\begin{array}{c}\text { Total DNA } \\
\text { (pmol) }\end{array}$ & $\begin{array}{c}\text { Infective cen- } \\
\text { ters }\end{array}$ & Percent efficiency & $\begin{array}{c}\text { Relative effi- } \\
\text { ciency }\end{array}$ \\
\hline Control & & & 10 & 5,024 & $6.7 \times 10^{-3}( \pm 65 \%)$ & 1 \\
$\mathrm{~T} 7_{3}$ & 1.15 & 1.62 & 2.77 & 73,950 & $3.6 \times 10^{-1}( \pm 70 \%)$ & 53.2 \\
$\mathrm{~T} 7_{3,6} \mathrm{HH}$ & 2.20 & 0.11 & 2.31 & 350 & $2.0 \times 10^{-3}( \pm 65 \%)$ & 0.30 \\
$\mathrm{~T} 7_{3,6} \mathrm{HL}$ & 1.91 & 1.32 & 3.23 & 4,225 & $1.7 \times 10^{-2}( \pm 70 \%)$ & 2.6 \\
$\mathrm{~T} 7_{3,6} \mathrm{LL}$ & 0.20 & 0.89 & 1.09 & 517 & $6.3 \times 10^{-3}( \pm 55 \%)$ & 0.95 \\
\hline
\end{tabular}

${ }^{a}$ Extracts prepared from strain $\mathrm{W} 3110$ infected with $\mathrm{T} 7_{3}$ or $\mathrm{T} 7_{3,6}$ were incubated for 20 min at $30^{\circ} \mathrm{C}$ with 30 nmol of ${ }^{3} \mathrm{H}^{13} \mathrm{C}^{15} \mathrm{~N}$-labeled wild-type T7 DNA $(8.5 \mathrm{cpm} / \mathrm{pmol})$ per ml of reaction mixture; [ $\left.{ }^{32} \mathrm{P}\right] \mathrm{dATP}$ was present at $8.5 \mathrm{cpm} / \mathrm{pmol}$. Reactions were terminated by addition of EDTA and NET buffer. CsCl gradients were prepared, centrifuged, and collected as described in the legend to Fig. 8. Samples of each fraction were removed and acid precipitated as described in the legend to Fig. 2. Radioactivity was determined, and the amounts of ${ }^{3} \mathrm{H}$ and ${ }^{32} \mathrm{P}$-labeled DNA were calculated, yielding profiles similar to those shown in Fig. 2 and Fig. 8B. The DNA from the single peak resulting from synthesis in the $\mathrm{T} 7_{3}$-infected extract and the fully heavy, hybrid-density, and fully light DNAs resulting from synthesis in the T7 $7_{3,6}$-infected extract were dialyzed; a 10- $\mu$ l aliquot of each DNA was acid precipitated and filtered; and the radioactivity was determined. Control (unlabeled) DNA and $10-\mu$ portions of each of the DNAs synthesized from the $T 7_{3}$ - and $T 7_{3,6}$-infected extracts were incubated in the in vitro packaging system as previously described. The resulting phage were plated; strain W3110 was employed as indicator to give the numbers of infective centers indicated in the table.

the reaction using $\mathrm{T}_{3,6}$-infected cells were dialyzed, as was DNA from the single peak recovered after synthesis in an identical reaction using a $\mathrm{T}_{3}$ mutant. These DNAs were packaged in vitro. Again, the hybrid-density DNA from the reaction using $T 7_{3,6}$ phage showed greater packaging efficiency than either the fully heavy or fully light material. The DNA recovered after in vitro DNA synthesis carried out by an extract from $\mathrm{T} 7_{3}$-infected cells had significantly higher packaging efficiency than any of the other DNAs. Thus, the fast-sedimenting DNA structures formed in vitro appear to have biological significance, since they act as an especially good substrate for in vitro packaging.

\section{DISCUSSION}

A system for the in vitro synthesis of complete phage particles using exogenous DNA as the source of genetic information offers a potentially valuable tool for the study of DNA replication and DNA maturation, since such a system would allow measurement of the biological activity of the product DNA to be used as an end point. The experiments reported here were designed to test the ability of T7 DNA synthesized in vitro to be encapsulated into phage heads in a separate in vitro reaction so as to form infective phage particles bearing the genotype of the exogenous DNA substrate. Our experiments have also inquired, indirectly, as to the role of recombination in the formation of progeny phage by comparing the structure and the packaging efficiency of DNA synthesized in vitro in the presence or absence of T7 gene 6 exonuclease, an enzyme known to be involved in recombination and concatemer formation $(21,25,32)$. The results have shown striking differences in the sed- imentation patterns and the biological activity of DNA synthesized in vitro by extracts prepared from $\mathrm{T} 7_{3^{-}}$and $\mathrm{T} 7_{3,6}$-infected $E$. coli; electron microscopy has confirmed differences in the structure of DNA synthesized by extracts prepared from these two mutants.

The data presented in Fig. 1 and 2 and in Tables 2 and 4 clearly demonstrate that DNA synthesized in vitro can be packaged in vitro to form complete phage and that this packaging occurs with an efficiency comparable to that found when highly purified T7 virion DNA is packaged. In every experiment, it was found that the hybrid-density DNA synthesized by an extract prepared from $\mathrm{T} 7_{3,6}$-infected $E$. coli produced wild-type phage with higher efficiency than did the fully heavy (unreplicated) or fully light (replicated at least twice) DNA. This may mean that the DNA recovered from this peak is in some special configuration that increases the likelihood of packaging. A simpler explanation is that the hybrid-density DNA is enriched with molecules that have completed a single round of replication, are nearly full length, and contain a more even distribution of early and late $\mathrm{T} 7$ genes than do partially replicated molecules found in other portions of the gradient. Another point of interest is our observation that the duplex DNA replicated completely in vitro (fully light) forms viable wild-type phage with an efficiency comparable to that found with the virion DNA which presumably carries complete genetic information. This suggests that the in vitro packaging system may be able to modify DNA molecules with replication forks to make them suitable for encapsulation. Or it may be that only complete (or nearly complete) molecules, without replication forks, are selected for packaging. 
It is not clear how DNA molecules synthesized in vitro are terminated so that they contain complete genetic information. The model proposed by Watson to explain the termination requires recombination and formation of concatemers (49); however, as shown in Fig. 6, most of the DNA synthesized by extracts prepared from $T 7_{3,6}$-infected $E$. coli is no longer than a single $\mathrm{T} 7 \mathrm{chromosome}$. It may be that concatemers do form a small component of the total DNA, as has been found with $T 7_{3,6}$ mutants in vivo (10, 32). It might also be true that some concatemer formation (perhaps independent of gene 6) occurs during the in vitro reaction in which packaging takes place. While the gene rescue experiment in Table 2 argues against recombination with the endogenous DNA, it does not eliminate the possibility that end-to-end concatemer formation normally occurs as part of the maturation process. Previous in vivo evidence (32) suggests that normal phage recombination is not essential for concatemer formation. In fact, the concatemer formation envisioned in Watson's model may not require the gene 6 product. The data reported here indicate that when the gene 6 exonuclease is active several T7 DNA molecules are joined together during in vitro DNA synthesis performed by extracts from $\mathrm{T} 7_{3}$-infected cells. Both the sedimentation patterns and the electron micrographs are reminiscent of observations from in vivo studies by other workers (34). Apparently, the complex structures are produced primarily by noncovalent bonding, since Fig. 7 and 9 show that some separation between the template and product DNA occurs in alkali. The molecular weight distribution in Fig. 7 and the skewing toward intermediate buoyant density in Fig. 9 suggest that some formation of end-to-end concatemers may have taken place. It may be that final closure of DNA molecules to form a covalent linkage is incomplete in this in vitro reaction, thus allowing separation after alkaline denaturation. Finally, the rapidly sedimenting DNA that we observe may include molecules that are undergoing recombination events in the midst of the molecule rather than at the termini. Branched structures like the ones in Fig. 10B and $\mathrm{C}$ have been observed many times during our experiments, and these molecules appear similar to ones observed by Broker and Lehman (2) in their study of recombination in bacteriophage $\mathrm{T} 4$ in the absence of DNA synthesis. However, it should be kept in mind that the molecules in Fig. 10 are actively replicating, and forked and branched structures may arise from multiple (perhaps aberrant) initiation events on the same DNA molecule or concatemer.

A peripheral observation during our experi- ments was the detection of DNA in a complex of very low buoyant density in the $\mathrm{CsCl}$ gradients in Fig. 8. Although deproteinization releases the DNA from this complex, it is not immediately obvious why this low-density material is found only in the experiments using $\mathrm{T} 7_{3^{-}}$ infected cells. Perhaps the presence of singlestranded regions created by the gene 6 exonuclease allows attachment of DNA binding proteins in quantities sufficient to alter the buoyant density of the molecules. A more intriguing possibility is that, since the rapidly sedimenting structures are a preferred substrate for packaging, there may be some capsid attachment to the DNA during the in vitro DNA synthesis reaction.

Irrespective of the origin of the fast-sediment,ing DNA synthesized by extracts prepared from $\mathrm{T} 7_{3}$-infected cells, it is clear that formation of these complex structures significantly enhances the ability of the DNA to be encapsulated into phage heads. This may be because the DNA in the fast-sedimenting complexes is genetically more complete or because the enzymatic machinery responsible for DNA packaging recognizes at least some component of these complexes as a preferred substrate for encapsulation. The observation of fast-sedimenting forms of DNA in vivo $(10,17,34,42,45)$ encourages speculation that structures like the one in Fig. 11 may be natural precursors for encapsulation of T7 DNA during normal phage morphogenesis.

\section{ACKNOWLEDGMENT}

This research was supported by the Department of Energy under contract with the Union Carbide Corporation.

\section{LITERATURE CITED}

1. Benzinger, R., I. Kleber, and W. D. Henner. 1973. Transfection of Escherichia coli spheroplasts. III. Facilitation of transfection and stabilization of spheroplasts by different basic polymers. J. Virol. 12:741-747.

2. Broker, T. R., and I. R. Lehman. 1971. Branched DNA molecules: intermediates in T4 recombination. J. Mol. Biol. 60:131-149.

3. Burgi, E., and A. D. Hershey. 1953. Sedimentation rate as a measure of molecular weight of DNA. Biophys. J. 3:309-321.

4. Center, M. S., F. W. Studier, and C. C. Richardson. 1970. The structural gene for a T7 endonuclease essential for phage DNA synthesis. Proc. Natl. Acad. Sci. U.S.A. 65:242-248.

5. Charlesby, A. 1954. Molecular-weight changes in the degradation of long-chain polymers. Proc. R. Soc. London Ser. A 224:120-128.

6. Davis, R. W., and N. Davidson. 1968. Electron microscope visualization of deletion mutations. Proc. Natl. Acad. Sci. U.S.A. 60:243-250.

7. Dressler, D., J. Wolfson, and M. Magazin. 1972. Initiation and reinitiation of DNA synthesis during replication of bacteriophage T7. Proc. Natl. Acad. Sci. U.S.A. 69:998-1002.

8. Ehrlich, S. D., V. Sgaramella, and J. Lederberg. 1976. 
Transfection of restrictionless Escherichia coli by bacteriophage T7 DNA: effect of in vitro erosion of DNA by $\lambda$ exonuclease. J. Mol. Biol. 105:603-609.

9. Freifelder, D. 1970. Molecular weights of coliphages and coliphage DNA. IV. Molecular weights of DNA from bacteriophages T4, T5, and T7 and the general problem of determination of M. J. Mol. Biol. 54:567-577.

10. Frohlich, B., A. Powling, and R. Knippers. 1975. Formation of concatemeric DNA in bacteriophage T7-infected bacteria. Virology 65:455-468.

11. Grippo, P., and C. C. Richardson. 1971. Deoxyribonucleic acid polymerase of bacteriophage T7. J. Biol. Chem. 246:6867-6873.

12. Hausmann, R. 1973. The genetics of T-odd phages. Annu. Rev. Microbiol. 27:51-67.

13. Hausmann, R. 1977. Bacteriophage T7 genetics. Curr. Top. Microbiol. Immunol. 75:77-110.

14. Hinkle, D. C., and C. C. Richardson. 1974. Bacteriophage T7 deoxyribonucleic acid replication in vitro Requirements for deoxyribonucleic acid synthesis and characterization of the product. J. Biol. Chem 249:2974-2984.

15. Hinkle, D. C., and C. C. Richardson. 1975. Bacteriophage $\mathrm{T} 7$ deoxyribonucleic acid replication in vitro Purification and properties of the gene 4 protein of bacteriophage T7. J. Biol. Chem. 250:5523-5529.

16. Inman, R. B., and M. Schnös. 1970. Partial denaturation of thymine and 5-bromouracil-containing $\lambda$ deoxyribonucleic acid in alkali. J. Mol. Biol. 49:93-98.

17. Kelly, T. J., and C. A. Thomas, Jr. 1969. An intermediate in the replication of bacteriophage T7 deoxyribonucleic acid molecules. J. Mol. Biol. 44:459-475.

18. Kerr, C., and P. D. Sadowski. 1972. Gene 6 exonuclease of bacteriophage T7. I. Purification and properties of the enzyme. J. Biol. Chem. 247:305-310.

19. Kerr, C., and P. D. Sadowski. 1972. Gene 6 exonuclease of bacteriophage T7. II. Mechanism of the reaction. J. Biol. Chem. 247:311-318.

20. Kerr, C., and P. D. Sadowski. 1974. Packaging and maturation of DNA of bacteriophage T7 in vitro. Proc. Natl. Acad. Sci. U.S.A. 71:3545-3549.

21. Kerr, C., and P. D. Sadowski. 1975. The involvement of genes $3,4,5$, and 6 in genetic recombination in bacteriophage T7. Virology 65:281-285.

22. Kleinschmidt, A. K., D. Long, D. Jacherts, and R. K. Zahn. 1962. Preparation and length measurements of the total deoxyribonucleic acid content of T2 bacteriophage. Biochim. Biophys. Acta 61:857-864.

23. Kolodner, R., and C. C. Richardson. 1977. Replication of duplex DNA by bacteriophage T7 DNA polymerase and gene 4 protein is accompanied by hydrolysis of nucleoside $5^{\prime}$-triphosphates. Proc. Natl. Acad. Sci. U.S.A. 74:1525-1529.

24. Kuemmerle, N. B., and W. E. Masker. 1977. In vitro packaging of UV radiation-damaged DNA from bacteriophage T7. J. Virol. 23:509-516.

25. Lee, M., and R. C. Miller. 1974. T7 exonuclease (gene 6) is necessary for molecular recombination of bacteriophage T7. J. Virol. 14:1040-1048.

26. Lee, M., R. C. Miller, D. Scraba, and V. Paetkau. 1976. The essential role of bacteriophage $\mathrm{T} 7$ endonuclease (gene 3) in molecular recombination. J. Mol. Biol. 104:883-888.

27. Masamune, Y., G. D. Frenkel, and C. C. Richardson. 1971. A mutant of bacteriophage $T 7$ deficient in polynucleotide ligase. J. Biol. Chem. 246:6874-6879.

28. Masker, W. E. 1977. Deoxyribonucleic acid repair in vitro by extracts of Escherichia coli. J. Bacteriol. 129: 1415-1423.

29. Masker, W. E., and C. C. Richardson. 1976. Bacteriophage T7 deoxyribonucleic acid replication in vitro. V. Synthesis of intact chromosomes of bacteriophage $\mathrm{T} 7$.
J. Mol. Biol. 100:543-556

30. Masker, W. E., and C. C. Richardson. 1976. Bacteriophage T7 deoxyribonucleic acid replication in vitro. VI Synthesis of biologically active T7 DNA. J. Mol. Biol. 100:557-567.

31. Miller, J. 1972. Experiments in molecular genetics. Cold Spring Harbor Laboratory, Cold Spring Harbor, N.Y.

32. Miller, R. C., M. Lee, D. G. Scraba, and V. Paetkau. 1976. The role of bacteriophage $T 7$ exonuclease (gene 6) in genetic recombination and production of concatemers. J. Mol. Biol. 101:223-234.

33. Modrich, P., and C. C. Richardson. 1975. Bacteriophage T7 deoxyribonucleic acid replication in vitro. Bacteriophage T7 DNA polymerase: an enzyme composed of phage- and host-specified subunits. J. Biol. Chem. 250:5515-5522.

34. Paetkau, V., L. Langman, R. Bradley, D. Scraba, and R. C. Miller, Jr. 1977. Folded, concatenated genomes as replication intermediates of bacteriophage T7 DNA. J. Virol. 22:130-141.

35. Richardson, C. C. 1966 . The 5 '-terminal nucleotides of T7 bacteriophage deoxyribonucleic acid. J. Mol. Biol. 15:49-61.

36. Roeder, G. S., and P. D. Sadowski. 1977. Bacteriophage T7 morphogenesis: phage-related particles in cells infected with wild-type and mutant T7 phage. Virology 76:263-285.

37. Sadowski, P. D. 1971. Bacteriophage T7 endonuclease. I. Properties of the enzyme purified from T7 phageinfected Escherichia coli B. J. Biol. Chem. 246: 209-216.

38. Sadowski, P. D. 1977. Genetic recombination of bacteriophage T7 DNA in vitro. II. Further properties of the in vitro recombination-packaging reaction. Virology 78:192-202.

39. Sadowski, P. D., and D. Vetter. 1976. Genetic recombination of bacteriophage T7 DNA in vitro. Proc. Natl. Acad. Sci. U.S.A. 73:692-696.

40. Scherzinger, E., and F. Liftin. 1974. In vitro studies on the role of phage T7 gene 4 product in DNA replication. Mol. Gen. Genet. 135:73-86.

41. Scherzinger, E., and D. Seiffert. 1975. Studies on bacteriophage T7 DNA synthesis in vitro. I. Resolution of the T7 replication system into its components. Mol. Gen. Genet. 141:213-232.

42. Serwer, P. 1974. Fast-sedimenting bacteriophage T7 DNA from T7-infected Escherichia coli. Virology 59:70-88.

43. Stratling, W., F. J. Ferdinand, E. Krause, and R. Knippers. 1973. Bacteriophage T7 DNA replication in vitro: an experimental system. Eur. J. Biochem. 38:160-169.

44. Stratling, W., and R. Knippers. 1973. Function and purification of gene 4 protein of phage T7. Nature (London) 245: 195-197.

45. Stratling, W., E. Krause, and R. Knippers. 1973. Fast sedimenting deoxyribonucleic acid in bacteriophage $\mathrm{T} 7$. infected cells. Virology 51:109-119.

46. Studier, F. W. 1969. The genetics and physiology of bacteriophage $T 7$. Virology 39:562-574.

47. Studier, F. W. 1972 . Bacteriophage T7. Science 176:367-376.

48. Vlachopoulou, P. J., and P. D. Sadowski. 1977. Genetic recombination of bacteriophage T7 DNA in vitro. III A physical assay for recombinant DNA. Virology 78:203-215.

49. Watson, J. D. 1972. Origin of concatemeric T7 DNA. Nature (London) New Biol. 239:197-201.

50. Wickner, W., D. Brutlag, R. Schekman, and A. Kornberg. 1972. RNA synthesis initiates in vitro conversion of M13 DNA to its replicative form. Proc. Natl. Acad. Sci. U.S.A. 69:965-969. 